\title{
OPTICAL AND ELECTRICAL PROPERTIES OF $\mathrm{Mn}^{2+}$ DOPED TITANIUM OXIDE THIN FILMS
}

\author{
M. P. D. Parimala ${ }^{1}$, M. Seshu Kumar ${ }^{1}$ and M.C. Rao ${ }^{2 *}$ \\ ${ }^{1}$ Research Scholar, Krishna University, Department of Physics, Andhra Loyola College, \\ Vijayawada-520 008, India \\ ${ }^{2}$ Department of Physics, Andhra Loyola College, Vijayawada-520 008, India \\ *E-mail: raomc72@gmail.com
}

\begin{abstract}
$\mathrm{Mn}^{2+}$ doped $\mathrm{TiO}_{2}$ thin films were prepared by sol-gel method. Optical, ionic conductivity, photoluminescence and chromaticity studies have been carried-out on to the prepared samples. The UV-visible spectrum consists of four bands at 578, 529, 432 and $368 \mathrm{~nm}$ and is assigned to d-d transitions. The ionic conductivity plot revealed that the conduction takes place by the variation of temperature, which is due to the motion of charge carriers in free space. The thermo emf of $\mathrm{Mn}^{2+}$ doped $\mathrm{TiO}_{2}$ thin films increased with the increase of temperature is due to conduction phenomenon from 275 to $325 \mathrm{~K}$. Photoluminescence (PL) spectrum showed the emission peaks at 462, 513 and 582 $\mathrm{nm}$ wavelengths. The luminescence source of the material and its functional values can be determined by the color coordinates, which is found to be in orange and yellow regions.
\end{abstract}

Keywords: $\mathrm{TiO}_{2}$, Sol-gel, UV-visible, Ionic conductivity, PL and CIE studies.

(C) RASĀYAN. All rights reserved

\section{INTRODUCTION}

Now a day's semiconductor materials based nanotechnology plays a crucial role in the development of optoelectronic devices. Nanotechnology controls the matter on the atomic and molecular scale. It includes making products such as electronic devices, catalysts, sensors, etc. When compared to the bulk materials thin film materials have many interesting properties, which brought in to focus on industrial and nanotechnology applications. Different types of techniques were used to fabricate thin films because thin films are having many interrelated parameters and excellent physical properties like easy of film formation, mechanical strength, and electrical conductivity etc. The nanostructured materials having excellent physical and chemical properties and are used in many applications like gas sensors ${ }^{1}$, electroluninence display ${ }^{2}$, electrochromic devices ${ }^{3}$, humidity sensors ${ }^{4}$, solar applications ${ }^{5}$ etc. Nano materials are good at optical, electronic and photoelectrochemical properties. Among all the metal oxides, titanium dioxide $\left(\mathrm{TiO}_{2}\right)$ is one of the most investigated materials and regarded as the best material for potential application by the researchers due to their interesting properties like no toxicity, low weight, higher band gap energy $(3.2 \mathrm{eV})$, stable chemical property and high dielectric constant ${ }^{6,7}$. Titanium dioxide thin film materials show the photocatalytic effect and also proposed for solar cell applications, laser diodes due to their thermal stability and high refractive index ${ }^{8} . \mathrm{TiO}_{2}$ is the best material for purification of water and air pollution treatments ${ }^{9}$. $\mathrm{TiO}_{2}$ thin films have been used for making products in many fields such as integrated circuits, solar cells, photo-electrodes etc.

A wide range of techniques have been reported, in order to prepare $\mathrm{TiO}_{2}$ thin films such as DC sputtering, spray pyrolysis, RF sputtering, spin coating, a sol-gel method, chemical vapor deposition (CVD) etc. Among these techniques, the sol-gel method is the best approach to deposit thin films with cost effective, easy control production on a large mass scale and also offer many advantages like the thickness of the films even by changing the concentration at low temperature using simple equipment ${ }^{10}$. Rao et al. published their results on different materials in the earlier studies. ${ }^{11-60}$

In the present investigation, $\mathrm{TiO}_{2}$ thin films were prepared by doping $\mathrm{Mn}^{2+}$ ions using the sol-gel method and the prepared films were characterized by UV-visible, ionic conductivity, PL and CIE studies. 


\section{Materials and Synthesis}

\section{EXPERIMENTAL}

Titanium IV isopropoxide ( $\mathrm{Ti}\left(\mathrm{OCH}\left(\mathrm{CH}_{3}\right)_{2}\right)_{4}$ was purchased from Sigma Aldrich Ltd., India with 98\% purity. Isopropyl alcohol $\left(\mathrm{CH}_{3}\right)_{2} \mathrm{CHOH}$ obtained from pure Merck Ltd., India with $98 \%$ purity, was used to synthesize the sols. Glacial acetic acid was used for hydrogenation process. The precursor solution is prepared with a molar ratio of 1.3 by mixing of $\left(\mathrm{Ti}\left(\mathrm{OCH}\left(\mathrm{CH}_{3}\right)_{2}\right)_{4}\right.$ and $\left(\mathrm{CH}_{3}\right)_{2} \mathrm{CHOH}$ under constant stirring, later Acetic acid was added drop wise to the alkoxide solution. A white precipitate is formed after 30 min under constant stirring. Finally, by adding the methanol and manganese oxide $(\mathrm{MnO})$ with a ratio of (1:8), a moonstone color precipitate was formed and it is placed for $60 \mathrm{~min}$ to settle down the precipitate. Soda lime glass (SLG) was dipped in the prepared sol during the time interval of 30 min and $60 \mathrm{~min}$. Both the SLG's are annealed at $500{ }^{\circ} \mathrm{C}$.

\section{Characterization}

UV-Visible spectrum is taken at room temperature using JASCO V-670 Spectrophotometer in the wavelength range $200-600 \mathrm{~nm}$. The ionic conductivity measurements were made on to the experimental films by employing four probe method. The thermo emf of the prepared samples was studied between the temperature ranges from 275 to $325 \mathrm{~K}$ using thermal probe method. Photoluminescence spectrum is taken at room temperature on Horiba Jobin-Yvon Fluorolog-3 spectrofluorimeter with Xe continuous (450 W) and pulsed $(35 \mathrm{~W})$ lamps as excitation sources. CIE (x, y) chromaticity coordinates are calculated from the spectral power distribution of the light source and the CIE color-matching functions. This is generated by MAT-lab software.

\section{UV-Visible Studies}

\section{RESULTS AND DISCUSSION}

The uv-visible spectrum of $\mathrm{Mn}^{2+}$ doped $\mathrm{TiO}_{2}$ thin films was carried-out on to the prepared films in the wavelength range 200-600 nm is shown in Fig.-1. The uv-visible spectrum consists of four bands at $578,529,432$ and $368 \mathrm{~nm}$ and the assigned transitions suggest an octahedral geometry around the $\mathrm{Mn}^{2+}$ ion, followed by the equations:

$$
\begin{aligned}
& { }^{6} \mathrm{~A}_{1 \mathrm{~g}}(\mathrm{~S}) \rightarrow{ }^{4} \mathrm{~A}_{1 \mathrm{~g}}(\mathrm{G})+{ }^{4} \mathrm{E}_{\mathrm{g}}(\mathrm{G}) \\
& { }^{6} \mathrm{~A}_{1 \mathrm{~g}}(\mathrm{~S}) \rightarrow{ }^{4} \mathrm{~T}_{1 \mathrm{~g}}(\mathrm{G}) \\
& { }^{6} \mathrm{~A}_{1 \mathrm{~g}}(\mathrm{~S}) \rightarrow{ }^{4} \mathrm{~T}_{2 \mathrm{~g}}(\mathrm{G}) \\
& { }^{6} \mathrm{~A}_{1 \mathrm{~g}}(\mathrm{~S}) \rightarrow{ }^{4} \mathrm{~T}_{2 \mathrm{~g}}(\mathrm{D}) \mathrm{T}
\end{aligned}
$$

The energy matrices for the values of B, C and Dq inclusive of Tree's correction parameter ' $\alpha$ ' which is calculated by diagonalizing the energy matrices given for $\mathrm{d}^{5}$ configuration. ${ }^{61}$ The energy matrices also depend on the nature of the chemical bond between the ligand and the dopant. The absorption bands are formed due to clusters between in vibrations of molecules, where the transition metal ions get exited form ground state to higher energy state which depends on the nature of the symmetry. ${ }^{62}$ By solving the above three equations $\mathrm{Dq}=848, \mathrm{~B}=848$ and $\mathrm{C}=2936 \mathrm{~cm}^{-1}$ values are evaluated. The observed values of the prepared thin films satisfy with the calculated values. The band position of $\mathrm{Mn}^{2+}$ doped $\mathrm{TiO}_{2}$ thin films and their values were given in Table-1.

Table-1: Observed and calculated band positions of $\mathrm{Mn}^{2+}$ doped $\mathrm{TiO}_{2}$ thin films

\begin{tabular}{c|c|c|c|c|c|c}
\hline \multirow{2}{*}{$\begin{array}{c}\text { Transitions from } \\
{ }^{6} \mathrm{~A}_{1 \mathrm{~g}}(\mathrm{~S})\end{array}$} & \multirow{2}{*}{$\begin{array}{c}\text { Wavelength } \\
(\mathrm{nm})\end{array}$} & \multicolumn{2}{|c|}{ Wavenumber $\left(\mathrm{cm}^{-1}\right)$} & \multirow{2}{*}{$\begin{array}{c}\mathrm{Dq} \\
\left(\mathrm{cm}^{-1}\right)\end{array}$} & $\begin{array}{c}\mathrm{B} \\
\left(\mathrm{cm}^{-1}\right)\end{array}$ & $\begin{array}{c}\mathrm{C} \\
\left(\mathrm{cm}^{-1}\right)\end{array}$ \\
\cline { 3 - 4 } & & Observed & Calculated & & & \\
\hline${ }^{4} \mathrm{~T}_{\mathrm{g}}(\mathrm{G})$ & 368 & 27,158 & 27,173 & & & \\
\hline${ }^{4} \mathrm{~T}_{2 \mathrm{~g}}(\mathrm{G})$ & 432 & 23,162 & 23,148 & 848 & 848 & 2936 \\
\hline${ }^{4} \mathrm{~A}_{1 \mathrm{~g}}(\mathrm{G})+{ }^{4} \mathrm{E}_{\mathrm{g}}(\mathrm{G})$ & 529 & 18,897 & 18,904 & & & \\
\hline${ }^{4} \mathrm{~T}_{2 \mathrm{~g}}(\mathrm{D})$ & 578 & 17,315 & 17,301 & & & \\
\hline
\end{tabular}


RASĀYAN J. Chem.

Vol. 10 | No. 3 |825 - 831 | July - September | 2017

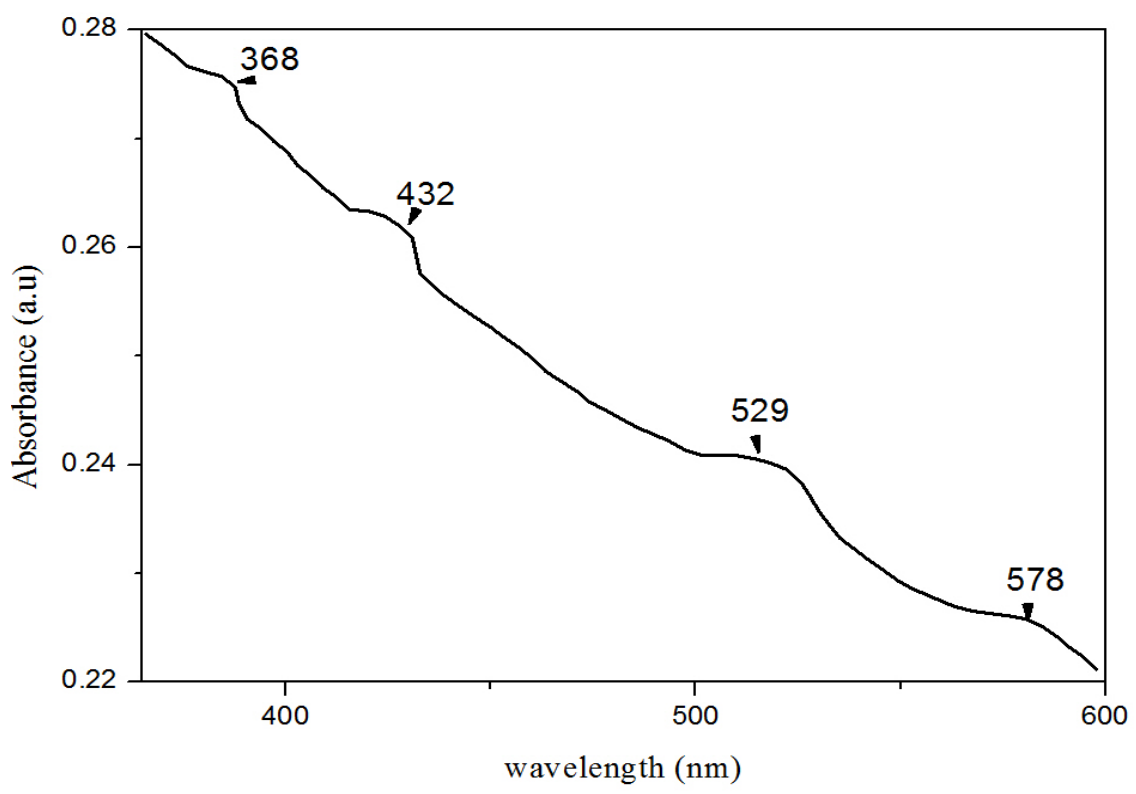

Fig.-1: Optical absorption spectrum of $\mathrm{Mn}^{2+}$ doped $\mathrm{TiO}_{2}$ thin films

\section{Electrical Properties}

The measurement of ionic conductivity was performed on to the prepared thin films using lab made fourprobe method. In this method inversion of temperature is varied with respect to logarithmic resistance (R) on to the prepared thin films which are shown in Fig.-2. The electrical resistance is found to vary as:

$$
\mathrm{R}=\mathrm{R}_{0} \exp (\Delta \mathrm{E} / \mathrm{KT})
$$

Where $\Delta \mathrm{E}$ is the temperature variation which is attributed to two activation processes i.e. the intrinsic band is formed at higher temperature due to conduction phenomenon, whereas at lower temperature region the material processes semiconductor behavior, which is due to the motion of charge carriers in free space. From the figure, it is observed that as increasing the temperature, the ionic conductivity also increases abruptly due to free flow charge carriers in the conduction phenomenon. ${ }^{63,64}$

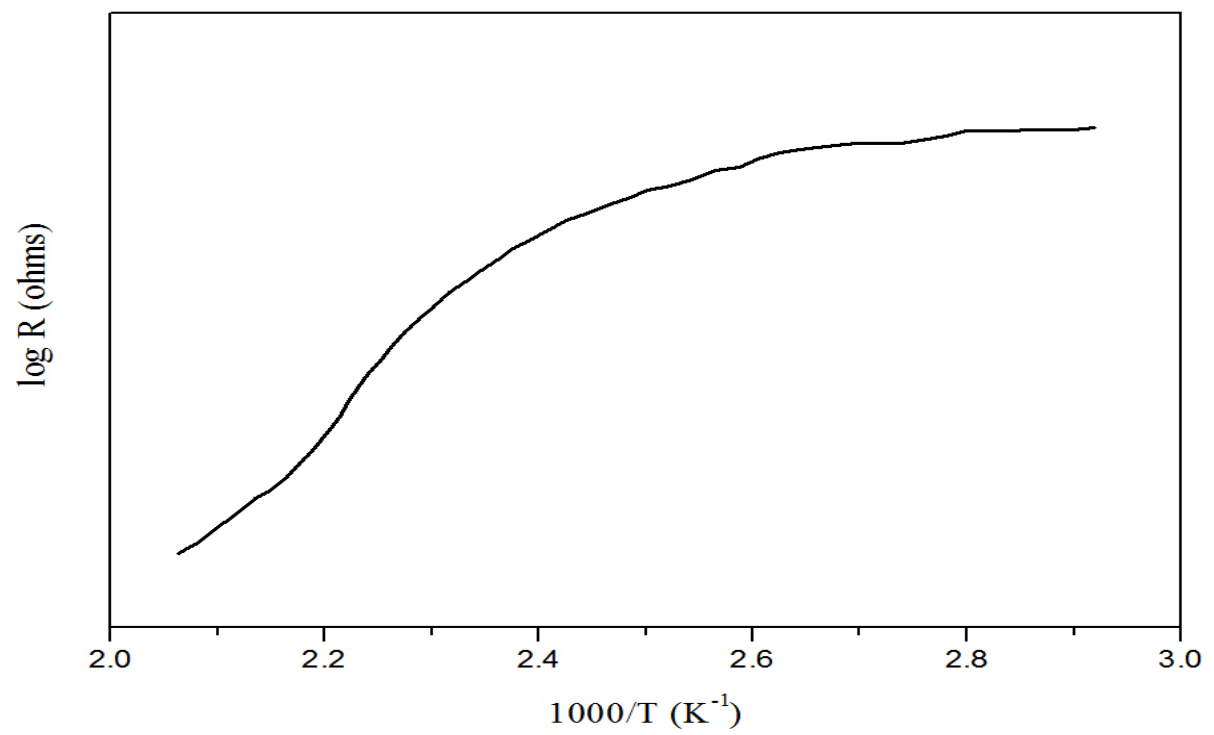

Fig.-2: Plot of $\log \mathrm{R}$ versus $1000 / \mathrm{T}$ of $\mathrm{Mn}^{2+}$ doped $\mathrm{TiO}_{2}$ thin films 
RASĀYAN J. Chem.

Vol. 10 | No. 3 |825 - 831 | July - September | 2017

\section{Thermo emf}

Thermo power or Seebeck coefficient of $\mathrm{Mn}^{2+}$ doped $\mathrm{TiO}_{2}$ thin films is measured by varying the temperature and magnitude of an induced thermoelectric voltage across the material using thermal probe method and thermal power can be calculated by the following equation:

$$
\mathrm{S}=-\Delta \mathrm{V} / \Delta \mathrm{T}
$$

Where ' $\mathrm{S}$ ' is the thermal power, which is measured from the conductivity plot. From Fig.-3 it is observed that with increasing the temperature the thermal emf is increased linearly due to characteristic conduction of $\mathrm{Mn}^{2+}$ doped $\mathrm{TiO}_{2}$ thin films. ${ }^{65.66}$ From the plot, the temperature difference can be measured between the two ends of the temperature which is found to be increased with respect to thermal emf due to conduction phenomenon. ${ }^{67}$

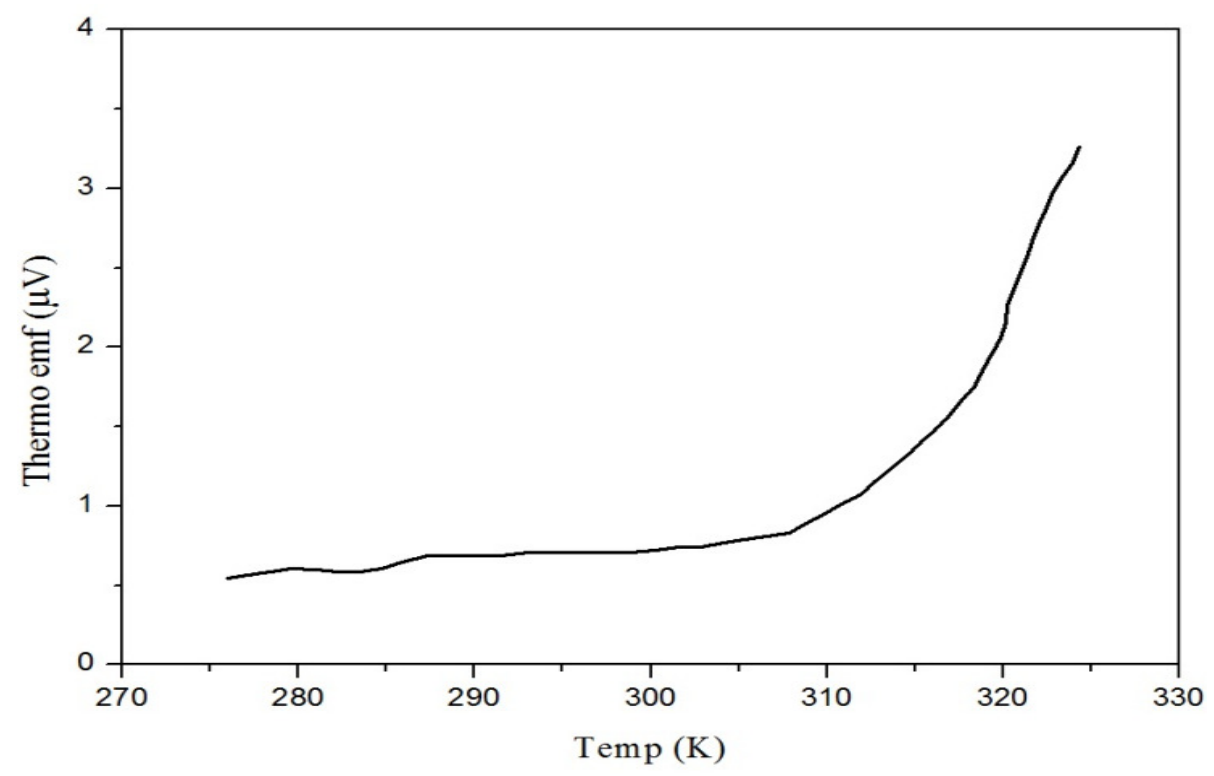

Fig.-3: Temperature dependence of the thermal emf of $\mathrm{Mn}^{2+}$ doped $\mathrm{TiO}_{2}$ thin films

\section{Photoluminescence Studies}

Photoluminescence spectrum of $\mathrm{Mn}^{2+}$ doped $\mathrm{TiO}_{2}$ thin film is shown in Fig.-4.The figure confirms that the PL spectrum consists of three bands formed at 462, 513 and $582 \mathrm{~nm}$ in the wavelength region 450$600 \mathrm{~nm}$, due to the exit of ions from the ground state to higher state in collision process, which corresponds to blue and yellow regions respectively. ${ }^{68}$ The intensity of the band which is observed at 462 $\mathrm{nm}$ is due to oxygen vacancies where the transition of electrons takes place in energy levels. Whereas the intensity of other bands is slightly increased, which are formed at 513 and $582 \mathrm{~nm}$. The intensity of band correlates with the variation in color due to the formation of single and double charged oxygen vacancies, which is observed in the orange and yellow region. ${ }^{69-75}$

Fig. -5 shows the color coordinates of $\mathrm{Mn}^{2+}$ doped $\mathrm{TiO}_{2}$ thin films, which is measured from the CIE 1931 chromaticity, and the $(x, y)$ color coordinate was found to be at $(x=0.5432, y=0.3397)$. The location of the color coordinates from the CIE chromaticity diagram is found in orange and yellow regions.

\section{CONCLUSION}

$\mathrm{Mn}^{2+}$ doped $\mathrm{TiO}_{2}$ thin films were prepared by sol-gel method. The UV-visible spectrum showed three characteristic bands and assigned transitions suggests an octahedral geometry this satisfies with the EPR studies. Electrical conducted is measured in two activation processes i.e. the intrinsic band is formed at higher temperature due to conduction phenomenon, whereas at lower temperature region the material processes semiconductor behavior, which is due to the motion of charge carriers in free space. Thermo 
emf of $\mathrm{Mn}^{2+}$ doped $\mathrm{TiO}_{2}$ thin films increased with the increase of temperature. PL spectrum consists of three bands formed at 462, 513 and $582 \mathrm{~nm}$, due to excitation of ions from the ground state to higher state in collision process. The location of the color coordinates from the CIE chromaticity diagram is found in orange and yellow regions. Based on the obtained results $\mathrm{Mn}^{2+}$ doped $\mathrm{TiO}_{2}$ thin films can be used for LEDs, electroluminescence panels, and plasma display panels.

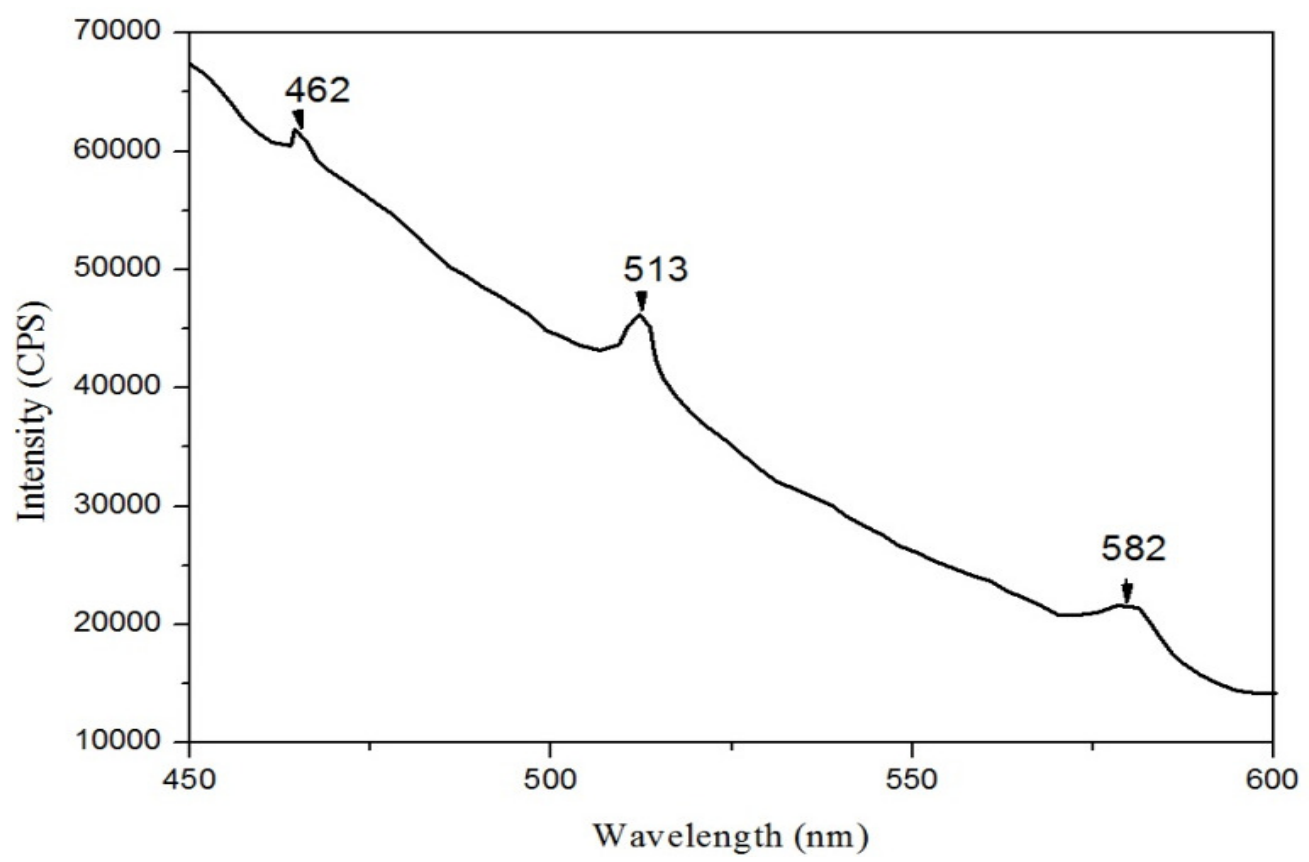

Fig.-4: PL spectrum of $\mathrm{Mn}^{2+}$ doped $\mathrm{TiO}_{2}$ thin films

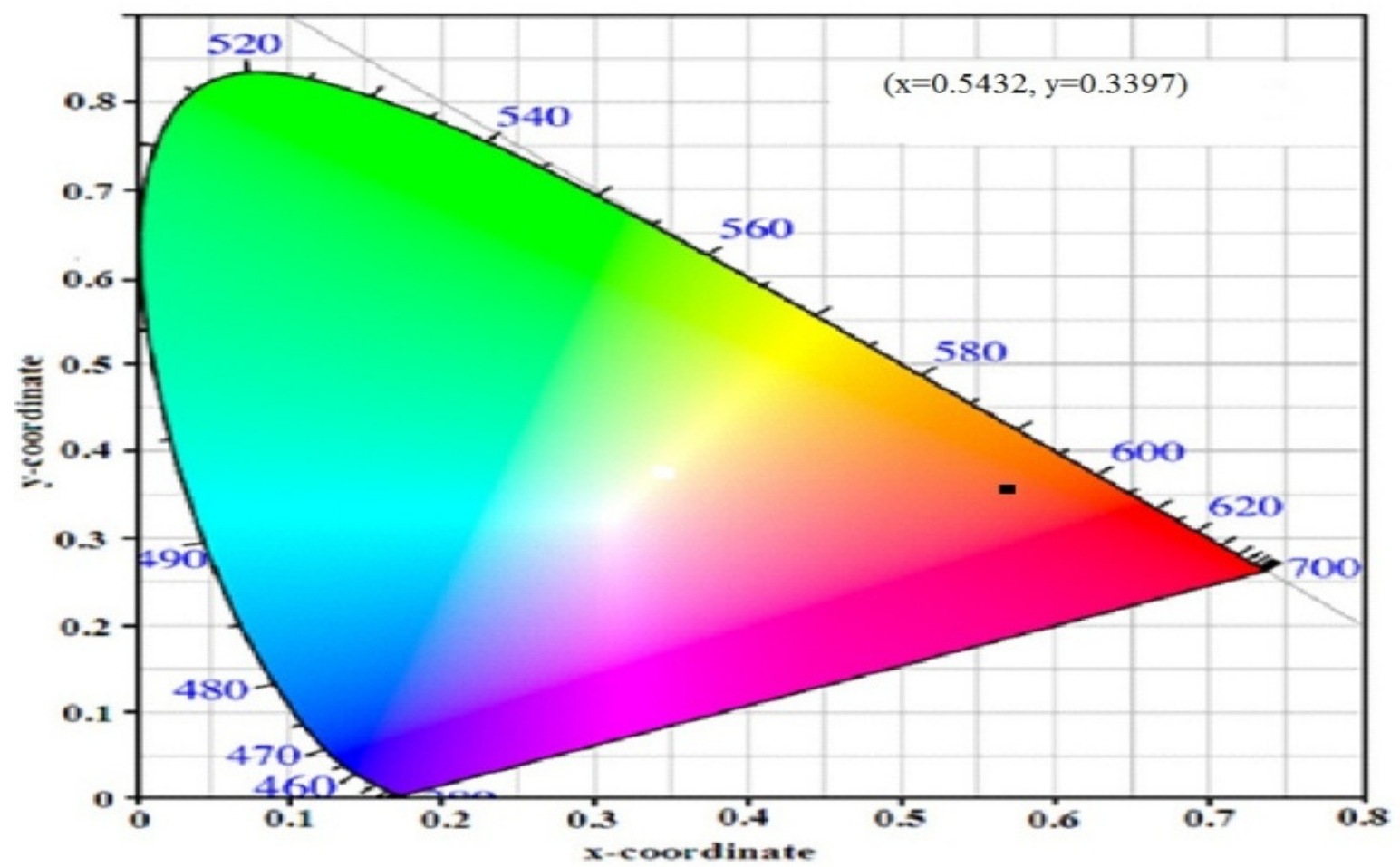

Fig.- 5: CIE diagram of $\mathrm{Mn}^{2+}$ doped $\mathrm{TiO}_{2}$ thin films 
RASĀYAN $J$. Chem.

Vol. 10 | No. 3 |825 - 831 | July - September | 2017

\section{REFERENCES}

1. C.X. Shan, X. Hou, K. Choy, Surf. Coating Tech., 202, 2399 (2008).

2. Z.L. Tang, J.Y. Zhang, Z. Cheng, Z.T. Zhang, Mater. Chem. Phys., 77, 314 (2001).

3. J.C. Yu, J.G. Yu, L.Z. Zhang, W.K. Ho, J. Photochem. Photobio. A: Chem., 148, 263 (2002).

4. Y.Z. Li, N.H. Lee, E.G. Lee, J.S. Song, S. Kim, Chem. Phys. Lett., 389, 124 (2004).

5. A.M. Ruiz, G. Sakai, A. Cornet, K. Shimanoe, J.R. Morante, N. Yamazoe, Sen. Actuators B:Chem., 103, 312 (2004).

6. S. Qiu,S. Kalita, Mater. Sci.Engg. A., 435, 327 (2006).

7. A. Fujishima, K. Honda, Nature, 238, 37 (1972).

8. T. Kim, T.K. Lee, M.N. Lee, S.H. Park, Thin Solid Films, 475, 171 (2005).

9. S. Angkaew, P. Limsuwan, Proc. Engg., 32, 649 (2012).

10. V. Brezova, J. Photochem. Photobio. A: Chem., 206, 177 (2009).

11. M.C. Rao, O.M. Hussain, J. Alloys Compd., 491(1), 503 (2010).

12. M.C. Rao, J. Crys. Growth, 312(19), 2799 (2010).

13. M.C. Rao, Optoelect. Adv. Mater., (Rapid Coтmu.) 5, 85 (2011).

14. Sk. Muntaz Begum, M.C. Rao, R.V.S.S.N. Ravikumar, Spectrochim. Acta Part A: Mol. Biomol. Spec., 98, 100 (2012).

15. M.C. Rao, J. Optoelect. Adv. Mater., 13, 428 (2011).

16. M.C. Rao, O.M. Hussain, Eur. Phys. J. Appl. Phys., 48(2), 20503 (2009).

17. Sk. Muntaz Begum, M.C. Rao, R.V.S.S.N. Ravikumar, J. Inorg. Organometa. Poly. Mater., 23(2), 350 (2013).

18. Sk. Shahenoor Basha, M.C. Rao, J. Inorg. Organomet. Polym. Mater., 27, 455 (2017).

19. M.C. Rao, J. Optoelect. Adv. Mater., 12, 2433 (2010).

20. M.C. Rao, O.M. Hussain, IOP Conf. Series: Mater. Sci. Eng., 2, 012037 (2009).

21. M.C. Rao, O. M. Hussain, Ind. J. Eng. Mater. Sci., 16, 335 (2009).

22. M.C. Rao, Optoelect. Adv. Mater., (Rapid Commu.) 5(5-6), 651 (2011).

23. M.C. Rao, O.M. Hussain, Optoelect. Adv. Mater., 13(2-4), 1109 (2011).

24. M.C. Rao, J. Optoelect. Adv. Mater., 13(1-2), 72 (2011).

25. M.C. Rao, Int. J. Chem. Sci., 10(2), 1111 (2012).

26. M. Tejaswi, M.C. Rao, P.V. Datta Prasad, G. Giridhar, V.G.K.M. Pisipati, R.K.N.R. Manepalli, Rasayan J. Chem., 9(4), 697 (2016).

27. M.C. Rao, Optoelect. Adv. Mater., (Rapid Commu.), 6, 511 (2012).

28. P.V. Prasad, K. Ramachandra Rao, M.C. Rao, J. Mol. Struc., 1085, 115 (2015).

29. M.C. Rao, J. Optoelect. \& Adv. Mater., 13, 78 (2011).

30. M.C. Rao, Sk. Muntaz Begum, Optoelect. Adv. Mater., (Rapid Commu.) 6, 508 (2012).

31. M.C. Rao, Res. J. Rec. Sci., 2(3), 67 (2013).

32. M.C. Rao, Int. J. Chem. Tech. Res., 6(3), 1904 (2014).

33. M.C. Rao, Optoelect. Adv. Mater., (Rapid Commu.) 4, 2088 (2010).

34. M.C. Rao, O. M. Hussain, Optoelect. Adv. Mater., (Rapid Commu.) 6, 245 (2012).

35. M.C. Rao, Res. J. Rec. Sci., 2(3), 67 (2013).

36. M.C. Rao, AIP Conf. Proc., 1728(1), 020077 (2016).

37. M.C. Rao, AIP Conf. Proc., 1447, 613 (2012).

38. M.C. Rao, AIP Conf. Proc., 1536, 27 (2013).

39. M.C. Rao, AIP Conf. Proc., 1536(1), 215 (2016).

40. M.C. Rao, Optoelect. Adv. Mater., (Rapid Commu.) 6, 245 (2012).

41. M.C. Rao, Optoelect. Adv. Mater., (Rapid Commu.) 10, 889 (2016).

42. P.V. Prasad, K. Ramachandra Rao, M.C. Rao, Int. J. Chem Tech Res., 7(1), 269 (2014).

43. M.C. Rao, Sk. Muntaz Begum, AIP Conf. Proc., 1447, 613 (2012).

44. K. Ravindranadh, M.C. Rao, Int. J. ChemTech Res., 9(4), 598 (2016).

45. Sk. ShahenoorBasha, K. Vijaya Kumar, M.C. Rao, Rasayan J. Chem., 9, 46 (2016).

46. K. Parameswara Rao, G.V. Ramana, M.C. Rao, Der Pharm. Lett., 8(13), 259 (2016). 
47. K. Ravindranadh, M.C. Rao, R.V.S.S.N. Ravikumar, J. Luminesce., 159, 119 (2015).

48. K. Ravindranadh, M.C. Rao, R.V.S.S.N. Ravikumar, J. Mater. Sci: Mater. Elect., 26, 6667 (2015).

49. K. Ravindranadh, B. Babu, M.C. Rao, R.V.S.S.SN. Ravikumar, Appl. Mag. Reson., 46 (1), 1 (2015).

50. K. Parameswara Rao, G.V. Ramana, M.C. Rao, Der Pharm. Lett., 8(10), 222 (2016).

51. M.C. Rao, K. Ravindranadh, A. Kasturi, M.S. Shekhawat, Res. J. Rec. Sci., 2(4), 1 (2013).

52. K. Parameswara Rao, G.V. Ramana, M.C. Rao, Rasayan J. Chem., 9(3), 393 (2016).

53. M.C. Rao, O.M. Hussain, Res. J. Chem. Sci., 1(7), 76 (2011).

54. M.C. Rao, J. Non-Oxide Glasses, 5, 1 (2013).

55. Sk. ShahenoorBasha, G.Sunita Sundari, M.C. Rao, Rasayan J.Chem., 9, 348 (2016).

56. J. Sivasri, M.C. Rao, G. Giridhar, B.T.P. Madav, T.E. Divakar, R. K.N.R. Manepalli, Rasayan J. Chem., 9(4), 556 (2016).

57. P. Jayaprada, 588 M. Tejaswi, G. Giridhar, M.C. Rao, V.G.K.M. Pisipati, R.K.N.R Manepalli, Rasayan J. Chem., 9(4), 588 (2016).

58. S. Rajyalakshmi, K. Ramachandra Rao, M.C. Rao, Int. J. ChemTech Res., 9(1), 7 (2016).

59. T. Samuel, K. Ramachandra Rao, M.C. Rao, AIP Conf. Proc., 1728 (1), 020080 (2016).

60. M.C. Rao, Int. J. Pure Appl. Phys., 6, 365 (2010).

61. R.K. Keswani,Collo. Surf. A: Physicochem. Engg., 369, 75 (2010) .

62. A. Kiselev, Surf. Sci., 584, 98 (2005).

63. J. Taranto, Sepa. Purifica. Tech., 67, 187 (2009).

64. J. Moon,Sen. Actuators B: Chem., 149, 301 (2010).

65. A.L. Ahmad, J. Membr. Sci., 366, 166 (2011).

66. S. Nad, J. Coll. Inter. Sci., 264, 89 (2003).

67. H.Y. Lee, G.M. Kale, Int. J. Appl. Ceram. Tech., 5, 657 (2008).

68. T. Guang-Lei, H. Hong-Bo, S. Jian-Da, Chin. Phys. Lett., 22, 1787 (2005).

69. F. Ungureanu, R. Medianu, R.V. Ghita, J. Optoelectr. Adv. Mater., 9, 1457 (2007).

70. Z. Li, M. Wu, T. Liu, Ultramicroscopy, 108, 1334 (2008).

71. A. Nakaruk, P.J. Reece, D. Ragazzon, C.C. Sorrell, Mater. Sci. Tech., 26, 469 (2010).

72. C.H. Wei, C.M. Chang, Mater. Trans., 52, 554 (2011).

73. W.S. Walailak, J. Sci. Tech., 11, 429 (2014).

74. M.M.L. Moreau, L.P. Granja, M.C. Fuertes, E.D. Martínez, V. Ferrari, P.E. Levy, J. Phys. Chem. C. 119, 28954 (2015).

75. W. Niu, G. Wang, X. Liu, J. Tang, X. Bi, Int. J. Electrochem. Sci., 10, 2613 (2015).

[RJC-1746/2017] 